14. Rischennja Lutskogo miskranogo sydy Volynskoi oblasti [The decision of Lutsk city district court of Volyn region] vid 05/04/2018 u spravi No.161/3673/18. URL: http://www.reyestr.court.gov.ua/Review/73195873 (in Ukrainian).

15. Rischennja Chechelnutskogo miskranogo sydy Vinnitskoi oblasti The decision of the Chechelnych District Court of Vinnytsia region] vid 21/02/2018 u spravi No. 151/69/18. URL: http://www.reyestr.court.gov.ua/ Review/72325507 (in Ukrainian).

16. Rischennja Vinnitskogo miskranogo sydy Vinnitskoi oblasti [The decision of the Vinnytsia city court of Vinnytsia region] vid 16/02/2018 u spravi No. 127/26894/17. URL: http: //www.reyestr.court. gov.ua/Review/72245829 (in Ukrainian)

17. Popov O. (2018). Maloznachni spravy jak protsessyalnyi filtr dostypy do sydy kasatsinoi instantsii: okremi putania sudovoi praktyky [Minor cases as a procedural filter of access to a court of cassation: some issues of case law]. Maloznachni spory: evropesikyi dosvid ta ukrainsiky dosvid vyrischennya: zbirnyk naukovyh pratsi uchasnykiv Miznarodnoi naukovo-praktychnoi konferentsii (Kyiv, lystopad 23-24, 2018). Kyiv, Ukraina / za zag. red. I. Izarova, R. Fleischer, R. Hanik-Pospolitak. Kyiv: Dakor. 134-147.

18. Rishennja ECHR u spravi "Levages Prestations Services v. France" [The decision of the European Court of Human Rights in Levages Presta- tions Services v. France] vid 10/23/96. URL: http://hudoc.echr.coe.int/ rus $\mathrm{i}=001-58065$ (in Ukrainian).

19. Rishennja ECHR u spravi "Brualla Gomez de la Torre v. Spain" [The decision of the European Court of Human Rights in "Brualla Gomez de la Torre v. Spain"] vid 12/19/97. URL: http: //hudoc.echr.coe.int/rus? I = 00158127 (in Ukrainian).

20. Uchvala Verhovnogo sydy [Order of the Supreme Court] vid 02.07.2018 po spravi No. 408/4122/17-c. URL: http://www.reyestr.court.gov.ua/ Review/75152533 (in Ukrainian).

21. Uchvala Verhovnogo sydy [Order of the Supreme Court] vid 12.04.2018 po spravi No. 210/1958 / 15-c. URL: http: //reyestr.court.gov.ua/ Review/73369044 (in Ukrainian).

22. Pojasnjuvalna zapyska do Zakony Pro vnesennia zmin do Hospodarskogo protsesualnogo kodeksu Ukrainy, Tsyvilnogo protsesualnogo kodeksu Ukrainy, Kodeksy administratyvnjho sudochunstva Ukrainy ta inshuh zakonodavchuh aktiv. No. 2314 vid 25.10.2019. URL: http://w1.c1.rada.gov.ua/pls/zweb2/webproc4_1?pf3511=67187 (in Ukrainian).

Received: $19 / 02 / 2020$ 1st Revision: $20 / 03 / 2020$ Accepted: $15 / 04 / 2020$

Zh. Vasylieva-Shalamova, PhD (Law), Associate Prof.,

I. Mamatiuk, Student

Taras Shevchenko National University of Kyiv, Kyiv, Ukraine

\title{
LEGISLATIVE REGULATION AND PRACTICAL IMPLEMENTATION OF SUMMARY PROCEEDING IN CIVIL LITIGATION
}

As a result of the reform of the Ukrainian Civil Procedural Law in 2017, civil justice has undergone significant changes. That is, - courts of first instance may consider civil cases in a general proceeding or in a summary proceeding.

The issue of legislative regulation and practical implementation of summary proceeding in civil litigation is in the focus of scientists and legal practitioners. To date, a separate Chapter 10 of Section III of the current Civil Procedure Code of Ukraine, which has the title - "Review of cases in summary proceedings" is devoted to a summary proceeding. This Chapter of the Civil Procedure Code of Ukraine determines the categories of cases to be considered in the procedure of summary proceedings, as well as the cases that cannot be considered in the procedure of summary proceeding, procedural features and the procedure for considering such cases.

At the same time, there are a number of disadvantages that cause certain problems that negatively affect to the theoretical basis and practical aspect of summary proceeding implementation in civil litigation in the part of the normative consolidation of the summary proceeding in the Civil Procedure Code of Ukraine.

Consequently, the issue of "minor cases" and the determination by courts of grounds for the consideration in summary proceeding of civil cases is the subject of our attention in this article.

Particularly these issues concern the lack of legal definition of the concept of "minor cases" at the legislative level, as well as the lack of clear criteria for assigning a particular case to the category of "minor" ones. Special attention should be paid to the effectiveness of the introduction of so-called "cassational filters" for minor cases in the current Civil Procedure Code of Ukraine.

The authors concluded that it is necessary to give a legitimate definition of the concept of minor cases and clear criteria for their definition as well as the fact that the institution of summary proceeding requires further improvement and development.

So, it is considered appropriate to draw attention to motivating the courts decisions, as well as wider application of the provisions of the principles of proportionality of civil judicial proceedings and cooperation between the parties and the court to ensure the realization of the main task - the effective protection of claimant's violated rights.

Keywords: summary proceeding; civil litigation; minor cases; cases of minor complexity; cassational filters.

Bulletin of Taras Shevchenko National University of Kyiv.

Legal Studies, 2020; 1 (112): 17-23

УДК: 347.122

DOI: https:doi.org/10.17721/1728-2195/2020/1.112-3
ISSN 1728-2195

Taras Shevchenko National University of Kyiv,

Publishing center "Kyiv University", 2020

І. Дзера, канд. юрид. наук, доц. Національний університет "Києво-Могилянська академія", Київ, Україна

\section{СИСТЕМА ЦИВІЛЬНО-ПРАВОВИХ САНКЦІЙ У ЗАГАЛЬНІЙ ЧАСТИНІ ЦИВІЛЬНОГО КОДЕКСУ УКРАЇНИ}

Досліджено норми книг 1-3 Цивільного кодексу України з метою визначення цивільно-правових санкцій. 3'ясовано відсутність у Цивільному кодексі України терміна "санкція" та окремих її видів, крім ст. 354, у якій наведено один вид санкції - конфіскація. Зазначені прогалини призводять до проблем у визначенні підстав для застосування тих чи інших заходів примусового характеру та перешкоджають ефективному захисту порушеного суб'єктивного цивільного права.

Здійснено критичний аналіз кількох існуючих класифікацій цивільно-правових санкцій та запропоновано власну класифікацію санкцій у Загальній частині Цивільного кодексу, залежно від видів правовідносин, що врегульовані ним. Для здійснення такої класифікації враховувалися: суб'єктний склад правовідносин, спрямованість на відновлення порушеного суб'єктивного цивільного права або на відшкодування завданої шкоди та наслідки застосування цивільноправових санкцій.

Ключові слова: санкція, захист цивільних прав, цивільно-правова відповідальність, міри відповідальності.

Вступ. Цивільний кодекс України містить чимало норм, спрямованих на врегулювання відносин у сфері відповідальності за невиконання чи неналежне виконання зобов'язань, захисту цивільних прав та інтересів суб'єктів цивільних правовідносин. Найбільша кількість норм, що регулюють механізми захисту порушень зобо- в'язань, зокрема і санкції, зосереджена у кн. 5 ЦК України "Зобов'язальне право". Однак, незважаючи на досить детальну регламентацію відшкодування збитків за невиконання чи неналежне виконання зобов'язань, у ЦК України не вживається для позначення такого способу захисту термін "санкція". Єдиною нормою ЦК, у 
якій згадується термін "санкція", є ст. 354, у якій під санкцією розуміється застосування позбавлення права власності на майно за рішенням суду за вчинення правопорушення (конфріскація) [1]. Незважаючи на відсутність у ЦК переліку цивільно-правових санкцій, вони досить широко застосовуються в договірній та судовій практиці.

Однак у юридичній, зокрема і цивілістичній науці, не сорормувалася єдність поглядів щодо правової природи, змісту та видів санкцій, особливо в цивільному праві. Натомість слід відзначити досить велику кількість наукових досліджень санкцій у господарському праві, що обумовлено наявністю в Господарському кодексі України близько 20 статей, присвячених безпосередньо регулюванню господарських санкцій та їхньому застосуванню. Наприклад, господарські санкції були предметом досліджень таких представників науки господарського права, як В. Щербина, Д. Ліпницький, А. Болотов, С. Гапало та ін. Дослідженню санкцій у цивільному праві приділяли увагу М. Агарков, С. Алексєєв, С. Братусь, О. Иоффре, О. Лейст, Н. Кузнєцова, В. Луць, В. Надьон, І. Канзафарова та ін. Однак певна частина із цих досліджень була виконана в радянський період історії України, а інша - стосувалася досліджень цивільно-правової відповідальності. Зважаючи на це питання цивільноправових санкцій у цивілістичній науці $є$ малодослідженими в сучасний період.

Виклад основного матеріалу. Виокремлення в ЦК, інших актах цивільного законодавства конкретних санкцій $є$ доволі складним завданням, оскільки законодавцем вони, по-перше, такими не іменуються, подруге, цивільно-правові норми зазвичай не будуються за загальновизнаною класичною триелементною моделлю (гіпотеза, диспозиція та санкція).

У загальній теорії права 70-80-х рр. сфрормувався поділ юридичних санкцій на правовідновлювальні (спрямовані на усунення шкоди, завданої неправомірною поведінкою, на відновлення порушених прав, на забезпечення виконання обов'язків) і на штрафнні (спрямовані на застосування до порушника нових або додаткових обтяжень). Відображає основну суть цього поділу юридичних санкцій їхня класифрікація на міри захисту і міри відповідальності. При цьому міри захисту уособлюють правовідновлювальні санкції, а міри відповідальності - штрафні. Найвагоміший внесок у здійснення класифікації юридичних санкцій належить О. Лейсту, який особливу увагу приділив правовідновлювальним і штрафним санкціям, внаслідок чого він дійшов висновку про тотожність санкцій і мір відповідальності [4, с. 102-184]. С. Алексєєв зазначив, що достатньо понять санкції і її застосування, оскільки вони дозволяють висвітлити всі основні сторони примусу до виконання права та зберегти специфрічний історичний зміст, який вкладається в поняття "юридична відповідальність" і "захист" [5, с. 272]. Отже, фактично автор вважав, що юридична відповідальність і захист можуть бути складовими елементами поняття "юридичні санкції".

Водночас слід підкреслити, що зазвичай науковці зосереджували увагу на способах захисту, реалізація яких має здійснюватися лише за допомогою санкцій.

У сучасний період домінуючим у цивільному праві $€$ поділ санкцій на міри захисту та міри відповідальності. Певну підтримку отримує ідея поділу санкцій на міри відповідальності й оперативні санкції. При цьому авторами вкладається в ці поняття різний зміст, зокрема взаємовиключного характеру [2, с. 136-138].

Оригінальну позицію 3 цього питання зайняла В. Надьон, яка запропонувала внести до ЦК України нову статтю "Види санкцій" такого змісту:

"Частина 1. Конфріскаційні санкції - додаткові примусові заходи, пов'язані з безоплатним вилученням у дохід держави майна правопорушника.
Частина 2. Штрафнні санкції - додаткові примусові заходи, що застосовуються до правопорушника (боржника) незалежно від майнової шкоди, яку зазнав потерпілий внаслідок правопорушення, допущеного винного стороною.

Від конфріскаційних штрафні санкції відрізняються тим, що перші стягуються із правопорушника в дохід держави, тоді як другі - на користь сторони, яка зазнала збитків від правопорушника.

Частина 3. Компенсаційні санкції - додаткові заходи, які мають своїм призначенням відшкодування потерпілій стороні шкоди або збитків, спричинених правопорушником..." [3, с. 272].

Наведений автором класифікаційний поділ санкцій на конфіскаційні, штрафні та компенсаційні містить кілька вразливих положень. По-перше, перераховані види санкцій не повною мірою відображають усе розмаїття цивільно-правових санкцій. По-друге, автором не відображене співвідношення санкцій зі способами захисту цивільних прав, зазначених у ст. 16 ЦК України. Потретє, не окреслено критерії, за якими мають визначатися штрафні санкції. По-четверте, компенсаційні санкції автор обмежила лише стороною договірних відносин і не застерегла, що вони є мірами цивільно-правової відповідальності. Заради справедливості відзначимо: потім автор правильно стверджує, що цивільно-правова відповідальність може виникати як у договірних, так і в недоговірних (деліктних) зобов'язаннях [2, с. 281].

Автор наведеної класифікації $€$ прихильником концепції абсолютної самостійності категорій, у якій санкція $€$ лише додатком до цивільно-правової відповідальності і може застосовуватися або не застосовуватися з такою відповідальністю, а сама відповідальність може бути застосована без застосування санкції. Однак, на нашу думку, важко погодитись із запропонованою концепцією, адже в принципі не існує в реальному вимірі цивільно-правової відповідальності без ії̈ конкретизованої міри, відображеної в нормативній чи договірній санкції. 3 огляду на це для здійснення класифікаційного поділу санкцій необхідно брати за основу правові норми, насамперед ЦК України й аналізувати їх з урахуванням результатів досліджень загальної теорії та цивілістичної науки. При цьому особливо важливо враховувати специфіку структурної побудови цивільно-правових норм, переважній частині яких не притаманна класична триелементна структура у формі гіпотези, диспозиції та санкції. Крім того, не потрібно обмежуватися аналізом норм зобов'язального права, як це зазвичай роблять переважна частина дослідників, адже санкції можуть міститися і в інших правових інститутах, але в певній специфрічній формі та завуальованого змісту.

Ознайомлення зі ст. 1-14 перших двох глав ЦК України засвідчує відсутність у них норм, які б містили елементи санкцій. Відсутні такі норми і в гл. 4 "Захист цивільних прав та інтересів". Натомість у цій главі містяться статті, норми яких присвячені переліку способів захисту цивільних прав та інтересів. Саме вони обумовлюють об'єктивну необхідність встановлення таких правових інструментів, які б забезпечували реалізацію уповноваженими особами належних їм способів захисту. Зазначеними інструментами $€$, зокрема, відповідні санкції, які належить виявити внаслідок нашого дослідження. Виявити норми, у яких містяться певні ознаки, притаманні санкціям, можна звернувшись до положень гл. 4 ЦК. Наприклад, відповідно до ч. 1 ст. 27 ЦК правочин, що обмежує можливість фрізичної особи мати не заборонені законом цивільні права й обов'язки, є нікчемним.

Згідно із ч. 5 ст. 32 ЦК за наявності достатніх підстав суд за заявою батьків (усиновлювачів), піклуваль- 
ника, органу опіки та піклування може обмежити право неповнолітньої особи самостійно розпоряджатися своїм заробітком, стипендією чи іншими доходами або позбавити її цього права. Поза сумнівом, застосовуване судом зазначене обмеження неповнолітнього $\epsilon$ примусовим заходом з обмеженнями, а відтак і цивільно-правовою санкцією.

Особливої уваги заслуговує зміст ст. 33 ЦК, що має назву "Цивільно-правова відповідальність неповнолітньої особи" і складається із трьох частин, у яких передбачається особиста відповідальність неповнолітніх осіб за порушення договорів, укладених ними самостійно відповідно до закону або за згодою батьків (усиновлювачів), піклувальників, а також за шкоду, завдану нею іншій особі відповідно до ст. 1179 ЦК. На перший погляд, можна дійти висновку про наявність у цій статті норм, що закріплюють відповідні санкції. Насправді такий висновок оманливий, оскільки за наведеною конструкцією приховуються положення щодо обсягу дієздатності неповнолітніх осіб. Інша річ, що така конструкція наведеної правової норми, на нашу думку, має подвійне призначення, адже саме вона дає можливість застосовувати міри відповідальності (санкції) до неповнолітньої особи в разі порушення укладеного нею договору чи завдання шкоди іншим особам.

Утім, подальший аналіз статей зазначеної глави засвідчує наявність закріплених у них цілком реальних санкцій. Такими є норми: ст. 36, що передбачають обмеження цивільної дієздатності фізичної особи; ст. 37, що встановлюють правові наслідки обмеження цивільної дієздатності фізичної особи; ст. 39, що передбачають визнання фрізичної особи недієздатною; ст. 43, що передбачають визнання фрізичної особи безвісно відсутньою або зниклою безвісти; ст. 46, що передбачають оголошення фрізичної особи померлою, ст. $48^{1}$, що встановлюють можливість відкриття провадження у справі про неплатоспроможність фрізичної особи, яка $є$ нездатною виконати свої майнові зобов'язання і погасити борги, а також уведення процедури реструктуризації боргів боржника або визнання ії банкрутом. В усіх перерахованих випадках статті містять юридичні норми, що передбачають правові заходи, спрямовані на встановлення певних обмежень або обтяжень у правовому статусі фрізичної особи. Відповідно, їх можна вважати цивільноправовими санкціями, що обмежують або обтяжують особистий цивільно-правовий статус фрізичної особи за обставин, зазначених у наведених статтях.

У главі 4 ЦК $є$ також статті - антиподи ст. 36, 37, 39, 41, 43, 46, 47. Наприклад, у ст. 38 закріплено норми, спрямовані на поновлення цивільної дієздатності фізичної особи, цивільна дієздатність якої була обмежена, а у ст. 42 - норми про поновлення цивільної дієздатності фрізичної особи, яка була визнана недієздатною. Отже, можна стверджувати, що норми цих статей містять санкції, які відновлюють цивільноправовий статус фізичної особи, що спричиняє для неї позитивні правові наслідки.

Не можна обійти увагою зміст ст. 44 ЦК, якою передбачаються правила встановлення опіки над майном фрізичної особи, визнаної безвісно відсутньою або місце проживання якої невідоме. Зокрема, у ч. 1 цієї статті йдеться, що на підставі рішення суду про визнання фізичної особи безвісно відсутньою нотаріус за останнім місцем її проживання описує належне їй майно та встановлює над ним опіку. У цьому випадку опис майна та встановлення опіки можна розглядати як превентивну санкцію, спрямовану на охорону майнового статусу фрізичної особи.
Унікальною є структурна побудова норми ст. 48, у ч. 1 якої передбачено, що в разі появи фрізичної особи, яка була оголошена померлою, суд має скасувати рішення суду про оголошення фрізичної особи померлою за заявою цієї особи або іншої зацікавленої особи. За таких обставин наведена норма встановлює начебто обов'язок і водночас санкцію, яка має бути застосована судом.

У гл. 5 ЦК є ст. 52 "Цивільно-правова відповідальність фрізичної особи-підприємця", яка насправді не містить норм, що б встановлювали будь-які заходии цивільно-правової відповідальності. 3 огляду на це $є$ більше підстав вважати норми зазначеної статті такими, що визначають елементи дієздатності фрізичної особипідприємця. Натомість норму ст. 53 ЦК, що передбачає визнання фрізичної особи-підприємця банкрутом, можна вважати санаційною санкцією, спрямованою на стабілізацію майнового статусу такої особи.

Особливе місце в цивільному праві займає інститут опіки та піклування, якому присвячені ст. 55-79 гл. 6 "Опіка та піклування". У цих статтях передбачаються норми, якими, зокрема, визначаються завдання опіки та піклування, порядок та умови їхнього встановлення, особи, які можуть бути опікунами та піклувальниками, їхні права та обов'язки, але наявність очевидних санкцій важко простежується. Проте їх можна відшукати в деяких статтях цієї глави. Такими можна вважати норми ст. 60, 61, що передбачають встановлення опіки та піклування відповідно судом й органами опіки та піклування і спрямовані на превентивну охорону особистого та майнового статусу фізичної особи. Відповідно, можемо стверджувати, що тут мають місце охороннопревентивні санкції.

Існують певні особливості структурної побудови норм гл. 7 "Загальні положення про юридичну особу". У ст. 96 ЦК встановлюються правові засади відповідальності юридичної особи, яка не містить норм про ту чи іншу міру відповідальності, а відтак і про санкцію.

Водночас у цій главі можна знайти норми з елементами санкцій. Наприклад, згідно із ч. 1 ст. 103 ЦК, якщо здійснення мети установи стало неможливим або воно загрожує суспільним інтересам, то відповідний орган державної влади може звернутися до суду із заявою про визначення іншої мети установи за погодженням 3 органами управління установою, а згідно із ч. 3 цієї ж статті суд може змінити структуру управління установи, якщо це необхідно внаслідок зміни мети установи або 3 інших поважних причин. У зазначених нормах передбачається судовий порядок зміни мети установи та структури ії управління, які можуть вважатися санкціями, спрямованими на зміну зовнішнього та внутрішнього цивільно-правового статусу юридичної особи у формі установи.

Другим прикладом може служити норма ч. 1 ст. 110 ЦК, відповідно до якої юридична особа може бути ліквідована, зокрема, за рішенням суду через допущені при іï створенні порушення, які не можна усунути, за позовом учасника юридичної особи або відповідного органу державної влади. Наведена санкція, на відміну від попередньої, спрямована не на зміну правового статусу юридичної особи, а на повне її припинення як суб'єкта цивільного права. Отже, можна констатувати фракт закріплення в наведених двох прикладах санкцій, спрямованих на зміну та припинення цивільноправового статусу юридичної особи.

У системі норм, що регулюють діяльність юридичних осіб, окреме місце посідають корпоративні санкції (ч. 3 ст. 99, ч. 2 ст. 100 , ч. 3 ст. 122, ст. 124, ст. 125 , ст. $126,128,129,131,138,139)$. Детальніше вони регулюються окремими законами, що регламен- 
тують правовий статус окремих видів юридичних осіб корпоративного типу.

Глава 11 ЦК має назву "Відповідальність за зобов'язаннями держави Автономної республіки Крим, територіальних громад". Проте, незважаючи на таку назву, всі три статті (174, 175, 176), що входять до іï̈ складу, не містять конкретних мір відповідальності, а відповідно і санкцій, а відтак у них фрактично містяться норми, що визначають обсяг їхньої правоздатності та дієздатності.

Не містять санкцій статті гл. 12, 13, 15 ЦК. У гл. 14 "Цінні папери" міститься ст. 198, у ч. 2 якої закріплена норма про те, що володілець незаконно виготовленого або підробленого цінного паперу має право пред'явити особі, яка передала йому папір, вимоги про належне виконання зобов'язання, посвідченого цим папером, та про відшкодування збитків. Наведена норма дає підстави вважати, що в ній передбачені дві різні санкції одна спрямована на примусове виконання зобов'язального обов'язку, друга - на примусове застосування міри відповідальності у формі збитків.

Надзвичайно багатою на закріплення специфічних санкцій $є$ гл. 16 "Правочини". Їхня специфічність полягає у тому, що в нормах цієї глави передбачається два рівні санкцій. На першому рівні можливе примусове визнання правочину недійсним у разі встановлення факту недотримання стороною (сторонами) в момент його вчинення вимог, встановлених частинами першою-третьою, п'ятою та шостою ст. 203 ЦК. Іншими словами, недійсність $€$ такою санкцією, що унеможливлює набрання чинності неправомірними діями, які лише умовно можна назвати "правочином", та врешті припиняє правопорушення.

Санкції другого рівня, які $є$ досить чисельними і неоднорідними за своїм змістом, закріплені у ст. 216 та інших статтях гл. 16 ЦК і $є$ наслідком недійсності правочину. Вони можуть бути загальними, спеціальними та конфіскаційними.

Загальні наслідки передбачені ст. 216 ЦК, згідно з якою в разі недійсності правочину кожна зі сторін зобов'язана повернути другій стороні в натурі все, що вона одержала на виконання цього правочину, а в разі неможливості такого повернення, зокрема тоді, коли одержане полягає у користуванні майном, виконаній роботі, наданій послузі - відшкодувати вартість того, що одержано, за цінами, які існують на момент відшкодування. Під поверненням у цивілістичній доктрині розуміється реституція, що може бути односторонньою або двосторонньою. Реституційні санкції мають відновлювальнокомпенсаційну спрямованість і не є мірами цивільноправової відповідальності.

Водночас ч. 2 ст. 216 ЦК передбачає можливість відшкодування збитків та моральної шкоди, завданих у зв'язку з учиненням недійсного правочину винною стороною. У такому разі такі санкції мають усі ознаки цивільно-правової відповідальності. В окремих статтях гл. $16(221,222,226,227,229,230,232,233)$ деталізуються умови застосування загальних санкцій залежно від того чи іншого виду недійсного правочину.

До спеціальних санкцій можна віднести санкції, які передбачають стягнення збитків із винної сторони у подвійному розмірі (ст. 230, ст. 231 ЦК), що надає підстави їх вважати штраффними санкціями, "карального" характеру, що $є$ нетиповим явищем у цивільному праві.

Спеціальними можна вважати також санкції, які дозволяють суду визнавати певні правочини, що мають окремі вади, дійсними, наприклад, ч. 2 ст. 220 ЦК передбачає можливість визнання правочину дійсним, якщо між сторонами мала місце домовленість щодо усіх істотних умов договору та відбулося його повне або часткове виконання, але одна зі сторін ухилилася від його нотаріального посвідчення, яке за законом є обов'язковим.

Можуть бути визнані судом дійсними правочини, учинені малолітніми, без дозволу органу опіки та піклування, недієздатними фізичним особами, відповідно до умов, визначених ч. 2 ст. 221 , ч. 2 ст. 224, ч. 2 ст. 226 ЦК України.

У наведених випадках законодавець, фрактично, надав судам право "узаконювати" правочини, учинені 3 порушенням вимог закону, тобто відбувається процес легалізації такої категорії відносин. 3 огляду на це $€$ підстави стверджувати про закріплення в наведених статтях "легалізаційних" санкцій. Надання суду таких повноважень не можна однозначно оцінювати негативно. Застосування санкції щодо визнання правочину дійсним має свою позитивну роль, адже воно спрямоване на захист "слабкої сторони".

Нарешті, у гл. 16 ЦК міститься ст. 228, яка певною мірою $є$ унікальною за своїм змістом. Ця унікальність, насамперед, полягає у тому, що вона передбачає правові наслідки вчинення правочину, який порушує публічний порядок, учинений з метою, що суперечить інтересам держави і суспільства, у формі стягнення зі сторін (сторони), якщо вони діяли з умислом, усього одержаного в дохід держави. Таке стягнення, фрактично, $€$ єдиною в ЦК конфіскаційною санкцією. Аналогічна норма $€$ також у ст. 208 ГК України, але яка істотно редакційно і змістовно відмінна від ст. 228 ЦК України.

Відсутні ознаки санкцій у нормах гл. 17 та гл. 18 ЦК.

Нечисельні, але цікаві санкції можна відшукати у гл. 20, 21 кн. 2 "Особисті немайнові права фрізичної особи". Наприклад, відповідно до ст. 276 ЦК, у разі порушення особистого немайнового права фрізичної особи рішеннями, діями або бездіяльністю органу державної влади, органу влади АРК, органу місцевого самоврядування, фрізичної або юридичної особи і невжиття ними необхідних дій для його негайного поновлення, суд може постановити рішення щодо поновлення порушеного права, а також відшкодування завданої ним моральної шкоди. Незважаючи на відсутність у цій статті посилання на вид і зміст порушеного особистого немайнового права, можна вважати наведену норму такою, що встановлює санкцію, спрямовану на поновлення порушеного особистого немайнового права.

Більш конкретизованою $є$ норма ч. 1 ст. 277 ЦК, відповідно до якої фрізична особа, особисті немайнові права якої порушено внаслідок порушення про неї (або) членів її сім'ї недостовірної інформації, має право на відповідь, а також на спростування цієї інформації. Прийняття судом рішення про спростування недостовірної інфрормації якраз і буде спростувальною санкцією, яка припиняє дію, що порушує право.

Дві санкції закріплені у ст. 278 ЦК. Відповідно до першої суд може в разі порушення особистого немайнового права фрізичної особи в газеті, книзі, кінофрільмі, теле-, радіопередачі тощо, що готуються до виходу у світ, заборонити розповсюдження відповідної інфоомації.

Відповідно до другої суд може в разі порушення особистого немайнового права фізичної особи випущеними у світ вищеперерахованими інформаційними засобами заборонити (припинити) їх розповсюдження до усунення цього порушення, а якщо це неможливо - вилучити тираж газети, книги тощо з метою його знищення.

Отже, і в першому й у другому випадках мають місце санкції, спрямовані, відповідно, на заборону вчинення певних дій, а відтак мають ознаки заборонних санкцій.

Стаття 280 ЦК передбачає право фрізичної особи, особисте немайнове право якої порушено, вимагати відшкодування майнової та/або моральної шкоди. Така 
норма є загальною і не встановлює певної нової санкції, оскільки правові наслідки порушення такого права безпосередньо передбачені у ст. 16 ЦК.

У гл. 21 "Особисті немайнові права, що забезпечують природне існування фрізичної особи" у ст. 293 ЦК (ч. 2) передбачена норма, яка надає суду право припинити діяльність фрізичної та юридичної особи, що завдає шкоди довкіллю. Отже, тут має місце санкція, спрямована на припинення незаконних дій.

Кілька санкцій закріплено в нормах гл. 22 "Особисті немайнові права, що забезпечують соціальне буття фрізичної особи". Наприклад, відповідно до ч. 3 ст. 297 ЦК фрізична особа має право звернутися до суду з позовом про захист її гідності та честі. На жаль, норма зазначеної статті має істотні вади, адже, по-перше, в ній не визначені позовні вимоги щодо способу захисту порушеного права, по-друге, невідомою $є$ санкція, яку в такій ситуації повинні застосовувати. Аналогічні вади притаманні також ч. 2 ст. 299 ЦК, згідно з якою фрізична особа може звернутися до суду з позовом про захист своєї ділової репутації. За таких обставин, як ми вважаємо, необхідно керуватися загальними положеннями ст. 16, 22, 23 ЦК, що дозволяють суду захистити гідність і честь фрізичної особи, а також її ділову репутацію шляхом стягнення 3 порушника майнової та моральної шкоди, що власне підтверджується нормою ст. 275 ЦК. А також захист може бути здійснений відповідно до ст. 276-278 ЦК шляхом поновлення порушеного права, спростування недостовірної інфрормації та заборони поширення інформації.

Проте в цій же главі міститься й інший приклад розв'язання такої проблеми. Так, відповідно до ч. 3 ст. 298 ЦК у разі глуму над тілом людини, яка померла, або над місцем ії̈ поховання члени її сім'ї, близькі родичі мають право на відшкодування майнової та моральної шкоди. Така норма передбачає критерії для визначення позовних вимог та застосовуваної санкції.

На особливу увагу заслуговують положення кн. 3 "Право власності та інші речові права", де міститься самостійна гл. 29 "Захист права власності". Проте і за межами цієї глави можна відшукати норми, що містять положення з ознаками санкцій. Наприклад, у ст. 346 ЦК наведено орієнтовний перелік підстав припинення права власності, зокрема і тих, які застосовуються незалежно чи всупереч волі власника. Такими є: а) примусове відчуження земельних ділянок приватної власності, інших об'єктів нерухомого майна, що на них розміщені, 3 мотивів суспільної необхідності відповідно до закону; б) звернення стягнення на майно за зобов'язаннями власника; в) реквізиція; г) конфіскація. У першому і другому випадках, безперечно, норми закріплюють повноцінні санкції. Реквізиція також може вважатися такою, адже у ст. 353 ЦК передбачені детально умови і підстави її застосування.

Дещо складнішою $є$ ситуація щодо конфіскації, якій також присвячена окрема ст. 354 ЦК, у ч. 1 якої йдеться, що до особи може бути застосовано позбавлення прав власності на майно за рішенням суду як санкція за вчинення правопорушення (конфіскація) у випадках, встановлених законом. Якщо вважати, що у наведеній статті маються на увазі цивільні правопорушення, то можна констатувати відсутність такого закону, який би встановлював цивільно-правову конффіскацію, за винятком ст. 228 ЦК, у якій хоч і не вживається термін "конфіскація", усе ж стягнення за недійсним правочином усього отриманого сторонами в дохід бюджету має ознаки цивільно-правової конфріскації.

У гл. 26 перераховуються норми, які надають суду право застосовувати примусові заходи, що мають певні ознаки санкцій. Такими є рішення судів про: а) переведення на співвласника прав та обов'язків покупця на співвласника у разі продажу частки у праві спільної власності з порушенням переважного права купівлі (ч. 4 ст. 362 ЦК); б) припинення права особи на частку у спільному майні (ст. 365 ЦК); в) виділення частки зі спільного майна в натурі для звернення стягнення на майно, що є у спільній сумісній власності (ст. 371).

У наведених випадках санкції є такими, що спрямовані на зміну або припинення правовідносин власності.

У гл. 27 ЦК "Право власності на землю (земельну ділянку) міститься ст. 376 "Самочинне будівництво", норми якої закріплюють дві санкції: перша спрямована на виникнення в особи права власності на самочинне будівництво (легалізаційна санкція), друга - на знесення самочинної будівлі (ліквідаційна санкція).

Не передбачають санкції норми гл. 28 "Право власності на житло". Натомість ця прогалина компенсується встановленням відповідних правових наслідків в інших законодавчих актах, що регулюють житлові відносини, наприклад, у Житловому кодексі України.

Особливий інтерес викликають норми гл. 29 "Захист права власності", адже сама назва вже обумовлює обов'язковість закріплення в ній примусово-правових заходів. Аналіз змісту статей цієї глави підтверджує висловлене припущення, але з певними застереженнями, які полягають в тому, що правові норми сформульовані 3 позицій захисту прав власника та можливих способів захисту, які мають бути закладені в позовні вимоги.

Наприклад, відповідно до ч. 2 ст. 386 ЦК власник, який має підстави передбачати можливість порушення права власності іншою особою, може звернутися до суду з вимогою про заборону вчинення нею дій, що можуть порушити його право, або з вимогою про вчинення певних дій для запобігання такому порушенню. Така норма для цивільного права $€$ досить рідкісною, адже захист цивільних прав та інтересів зазвичай здійснюється у разі їхнього реального порушення. У цьому випадку вимоги власника спрямовані на запобігання порушення, що може відбутися в майбутньому. Задовольняючи такі вимоги, суд має застосувати адекватну санкцію. За таких обставин тут має місце превентивна санкція.

Частина 2 ст. 286 ЦК, що передбачає право власника на відшкодування завданої йому майнової та моральної шкоди, фактично відтворює закріплений у ст. 16 ЦК аналогічний спосіб захисту порушених цивільних прав та інтересів. Проте навіть у такій редакції зазначені й інші норми дають суду можливість відповідно до заявленого способу захисту порушених прав власника застосувати адекватні їм санкції.

Узагальнюючи правові наслідки порушень права власності, можна дійти висновку про те, що суд може задовольнити позовні вимоги власника і постановити рішення про:

- витребування свого майна від особи, яка незаконно, без відповідної правової підстави заволоділа ним (ст. 387) з дотриманням вимог ст. 388 ЦК і передання його власнику;

- передання власнику (стягнення) усіх доходів, одержаних незаконним володільцем майна за умов, передбачених ч. 1, 2 ст. 390 ЦК;

- усунення перешкод у здійсненні власником права користування та розпорядження своїм майном (ст. 391 ЦК);

- визнання незаконним правового акта, що порушує право власності та його скасування за умов, передбачених уч. 1 ст. 393 ЦК; 
- відновлення становища власника, яке існувало до видання незаконного акта, а якщо це неможливо стягнути майнову та моральну шкоду з органа, що видав такий правовий акт (ч. 2 ст. 393 ЦК);

- стягнення компенсації на відшкодування шкоди, завданої власнику земельної ділянки, житлового будинку, інших будівель внаслідок діяльності, передбаченої ст. 394 ЦК.

У перерахованих випадках санкції мають відновлювально-компенсаційний характер, які можна назвати відновлювально-компенсаційні санкції у сорері захисту права власності, серед яких найвагоміше місце займають санкції про витребування майна й усунення перешкод у здійсненні права власності.

Особливе місце у гл. 29 ЦК займає ст. 392 ЦК "Визнання права власності", згідно з якою власник майна може пред'явити позов про визнання його права власності, якщо це право оспорюється або не визнається іншою особою, а також у разі втрати ним документа, що засвідчує його право власності. Специфіка таких позовів полягає, насамперед, у тому, що він не завжди пов'язаний із порушенням суб'єктивного права позивача та наявністю реального відповідача. Відповідно, відпадає потреба вести мову про застосування санкції.

Не містять істотних ознак способів захисту цивільних прав і відповідних санкцій гл. 30, 31, 32, 33, 34 ЦК. У випадку порушення прав суб'єктів відносин, урегульованих нормами зазначених глав, мають застосовуватися відповідні положення ст. 16 ЦК та гл. 29 ЦК.

Специфічними є способи захисту цивільних прав та санкції, що забезпечують реалізацію цих способів, які закріплені у кн. 4 ЦК "Право інтелектуальної власності". Наприклад, у гл. 35 "Загальні положення про право інтелектуальної власності" міститься окрема стаття, присвячена захисту права інтелектуальної власності (ст. 432). Відповідно до ч. 1 цієї статті кожна особа має право звернутися до суду за захистом свого права інтелектуальної власності відповідно до ст. 16 ЦК. Таким чином законодавець поширив загальні положення про способи захисту порушених прав та інтересів у сфері інтелектуальної власності. Проте положення ч. 2 цієї статті розкривають зміст конкретних заходів, які суд може вжити для забезпечення реалізації загальних способів захисту, передбачених у ст. 16 ЦК. У ній ідеться, що суд у випадках та в порядку, встановлених законом, може ухвалити рішення, зокрема, про:

- $\quad$ застосування негайних заходів щодо запобігання порушенню права інтелектуальної власності та збереження відповідних доказів;

- зупинення пропуску через митний кордон України товарів, імпорт чи експорт яких здійснюється 3 порушенням права інтелектуальної власності;

- вилучення із цивільного обороту товарів, виготовлених або введених у цивільний оборот із порушенням права інтелектуальної власності та знищення таких товарів;

- вилучення із цивільного обороту матеріалів і знарядь, що використовувалися переважно для виготовлення товарів із порушенням права інтелектуальної власності або вилучення та знищення таких матеріалів і знарядь;

- застосування разового грошового стягнення замість відшкодування збитків за неправомірне використання об'єкта права інтелектуальної власності. Розмір стягнення визначається відповідно до закону 3 урахуванням вини особи та інших обставин, що мають істотне значення;

- опублікування в засобах масової інформації відомостей про порушення права інтелектуальної власності та зміст судового рішення щодо такого порушення.
Отже, із зазначеного вище можна зробити висновок, що поданий перелік застосовуваних судом примусових заходів не є остаточним і законом можуть передбачатися й інші заходи. По-друге, цілком очевидно, на наш погляд, перераховані у ст. 432 ЦК заходи, що можуть бути застосовані судом до порушника, мають повноцінні ознаки цивільно-правових санкцій, які $є$ : превентивними (п. 1), заборонними (п. 2), ліквідаційними (п. 3, 4), компенсаційними (п. 5), інформаційними (п. 6).

Такий підхід до законодавчого закріплення санкцій є найефективнішим правовим інструментом забезпечення захисту порушених цивільних прав та інтересів.

Висновки. На підставі проведеного аналізу запропоновано виокремити такі види санкцій:

- У сфрері регулювання правового статусу фізичних та юридичних осіб:

- санкції, що обмежують або обтяжують особистий цивільно-правовий статус фрізичної особи (ст. 36, 37, 39, 43, 46 ЦК);

- санкції, що відновлюють цивільно-правовий статус фізичної особи, (ст. 38, 42);

- превентивні санкції, спрямовані на охорону майнового статусу фізичної особи (ст. 44);

- санаційні санкції (ст. 53);

- охоронно-превентивні санкції (ст. 60, 61);

- санкції, спрямовані на зміну зовнішнього та внутрішнього цивільно-правового статусу юридичної особи у формі установи (ст. 103);

- санкції, спрямовані на зміну та припинення цивільно-правового статусу юридичної особи. (ст. 110);

- корпоративні санкції (ч. 3 ст. 99; ч. 2 ст. 100; ч. 3 ст. 122; ст. 124, 125, 126, 128, 129, 131, 138, 139 ЦК).

- Санкції, що є наслідком недійсності правочинів: загальні (ст. 216 ЦК), спеціальні (ст. 220, 230, 231 ЦК) і конфіскаційні (ст. 228). Зі свого боку, серед спеціальних санкцій можна виділити штрафні та легалізаційні (ст. 221, 224, 226 ЦК).

- Санкції за порушення особистих немайнових прав особи можна поділити на поновлювальні, заборонні та спростувальні.

- Санкції за порушення права власності - спрямовані на зміну або припинення правовідносин власності, також легалізаційні та превентивні санкції.

- Відновлювально-компенсаційні санкції у сфрері захисту права власності, серед яких окремо можна виділити санкції про витребування майна й усунення перешкод у здійсненні права власності.

- Санкції за порушення у сорері інтелектуальної творчої діяльності, передбачені ст. 432 ЦК пропонується поділити на: превентивні (п. 1); заборонні (п. 2); ліквідаційні (п. 3, 4); г) компенсаційні (п. 5); інформаційні (п. 6).

Отже, на підставі викладеного вище, слід підкреслити: незважаючи на те, що в перших чотирьох книгах ЦК не зустрічається термін "санкція", крім одного випадку, однак аналіз норм зазначених книг засвідчив наявність великої кількості норм, що мають усі ознаки санкцій. Водночас усі вони є досить різними, мають абсолютно різну спрямованість і сутність, що обумовлено їхнім завданням - найефективний захист порушених цивільних прав.

Список використаних джерел:

1. Цивільний кодекс України від 16 січня 2003 р. (з наступними змінами та доповненнями станом на 31.10.2018). URL: http://zakon1.rada.gov.ua/laws/show/435-15

2. Пучковська І. Й. Теоретичні проблеми забезпечення зобов'язань: монограф. Харків: Право, 2017. 472 с.

3. Надьон В. В. Суб'єктивний обов'язок як елемент змісту цивільних правовідносин: монограф. Харків: Право, 2017. 392 с.

4. Лейст Е. Э. Санкции в советском праве. Москва, 1962. 238 с.

5. Алексеев С. С. Общая теория права: в 2 т. Москва: Юрид. лит., 1981. T. 1. $361 \mathrm{c}$ 


References
1. Tsyvilnyi kodeks Ukrainy vid 16 sichnia 2003 r. (z nastupnymy
zminamy ta dopovnenniamy stanom na 31.10 .2018$)$. URL:
http://zakon1.rada.gov.ua/laws/show/435-15 (in Ukrainian).
2. Puchkovs'kal. J. Teoretychni problemy zabezpechennja zobov'jazan':
monografija [Theoretical problems of securing obligations]. Harkiv: Pravo,
2017. 472 s. (in Ukrainian).
3. Nad'on V. V. Sub'jektyvnyj obov'jazok jak element zmistu cyvil'nyh
pravovidnosyn [Subjective obligation as an element of content in civil legal
relationships]: monografija. Harkiv : Pravo, $2017.392 \mathrm{~s}$. (inUkrainian).

4. Lejst E. Je. Sankcii v sovetskomprave [Sanctions in Soviet law]. M., 1962. 238 s. (in Russian).

5. Alekseev S.S. Obshhaja teorija prava [General Theory of Law]: $\vee 2$ tomah. T. 1. M.: Jurid. lit., 1981. 361 s. (in Russian).

Received: $10 / 02 / 2020$

1st Revision: $04 / 03 / 2020$

Accepted: $01 / 04 / 2020$

I. Dzera, PhD (Law), Associate Prof.

National University of Kyiv-Mohyla Academy, Kyiv, Ukraine

\section{THE SYSTEM OF CIVIL SANCTIONS IN THE GENERAL PART OF THE CIVIL CODE OF UKRAINE}

In this article the norms of Books 1-3 of the Civil Code of Ukraine are examined in order to determine civil sanctions and their system. The author stipulates that in the Civil Code of Ukraine there is no definition for the specific term "sanction" and its types, except for Article 354, which states only one type of the sanction, that is, confiscation. These gaps lead to the problems in determining the grounds for the application of certain measures of coercive nature and impede the effective protection of subjective civil law rights which are violated.

A critical analysis of existing classifications of civil sanctions is carried out, and an author's classification of the General Part of the Civil Code's sanctions is proposed, depending on the types of legal relationships governed by it. For the purposes of such classification, the author considers the subjective composition of the legal relationship, the focus on the restoration of the subjective civil law right, which is violated, or on the compensation of the harm caused, and the consequences of civil sanctions application.

A thorough analysis of the norms of Books 1-4 of the Civil Code is carried out in order to identify the norms containing civil sanctions. Thus, in the first three chapters of the Civil Code there is a lack of the norms containing civil sanctions. At the same time, Chapter 4 of the Civil Code is distinguished by the variety of civil sanctions that are proposed to be considered as civil sanctions that limit or impede the personal civil status of an individual in the circumstances specified in Articles 36, 37, 39, 41, 43, 46, 47, 481. Other provisions of the same chapter contain sanctions that restore the civil status of an individual, which causes him or her to have positive legal effects (Articles 38,42$)$ related to the restoration of the civil capacity of an individual whose civil capacity has been is limited or recognized as incompetent.

On the basis of the conducted research of the norms of the Civil Code, it is concluded that the diversity of civil legal sanctions in different chapters of the Civil Code, which have different directions and consequences of their application, despite the absence of their direct name "sanctions".

Keywords: a sanction, protection of civil rights, civil liability, measures of liability.

Bulletin of Taras Shevchenko National University of Kyiv. Legal Studies, 2020; 1 (112): 23-26

УдК: 347.921 .65

DOI: https:doi.org/10.17721/1728-2195/2020/1.112-4
ISSN 1728-2195

(C) Taras Shevchenko National University of Kyiv,

Publishing center "Kyiv University", 2020

Т. Коротенко, здобувач Київський університет права НАН України, Київ, Україна

\section{СУДОВІ ВИТРАТИ, ПОВ'ЯЗАНІ 3 ВИКОНАННЯМ СУДОВИХ ДОРУЧЕНЬ, ЗВЕРНЕНИХ ДО КОМПЕТЕНТНИХ ОРГАНІВ ІНОЗЕМНИХ ДЕРЖАВ}

Досліджено питання судових витрат, що пов'язані з виконанням судових доручень, які звернені до компетентних органів іноземних держав у цивільних справах з іноземним елементом. У ЦПК України не зазначено, що витрати, пов'язані з виконанням судових доручень, звернених до компетентних органів іноземних держав, є судовими витратами. У зв'язку із цим виникає питання щодо того, які саме із зазначених вище витрат можна віднести до судових, а також який порядок їхнього відшкодування. Важливість з'ясування цього питання полягає у застосуванні єдиних підходів до врегулювання таких справ у судах, що і є метою нашої статті. У висновках ми пропонуємо судові витрати, пов'язані із виконанням судових доручень, звернених до компетентних органів іноземних держав, поділити на види залежно від процесуальних дій, які здійснюються, а також віднести витрати, пов'язані з виконанням судових доручень, звернених до компетентних органів іноземних держав, до витрат, пов'язаних із розелядом справи, а саме до витрат, що пов'язані з учиненням інших процесуальних дій, необхідних для розеляду справи або підготовки до їі розгляду. Це забезпечить право зацікавленої сторони у майбутньому на відшкодування таких витрат.

Ключові слова: судові витрати, витрати, пов'язані з розглядом справи, справи з іноземним елементом, цивільне судочинство.

Вступ. Конвенція про захист прав людини й основоположних свобод [2], Рекомендація щодо заходів, які полегшують доступ до правосуддя № R (81)7, прийнята Комітетом міністрів Ради Європи 14 травня 1981 р. [3] та практика Європейського суду з прав людини під час застосування цієї Конвенції не визнають необхідність сплати судових витрат обмеженням права доступу до суду. Водночас, ураховуючи положення п. 1 ст. 6 Конвенції та прецедентну практику Європейського суду 3 прав людини (зокрема, рішення від 19 червня 2001 р. у справі "Креуз проти Польщі" (Kreuz v. Poland)) [4], сплата судових витрат не повинна перешкоджати доступу до суду, ускладнювати цей доступ таким чином і такою мірою, щоб завдати шкоди самій суті цього права, та має переслідувати законну мету.
Судові витрати - це передбачені законом витрати (грошові кошти) сторін, інших осіб, які беруть участь у справі, понесені ними у зв'язку з її розглядом та врегулюванням, а у випадках їхнього звільнення від сплати це витрати держави, які вона несе у зв'язку з розв'язанням конкретної справи. Відповідно до положень ст. 133 ЦПК України судові витрати складаються із судового збору та витрат, пов'язаних із розглядом справи.

До витрат, пов'язаних із розглядом справи, належать витрати:

1) на професійну правничу допомогу;

2) пов'язані із залученням свідків, фахівців, перекладачів, експертів і проведенням експертизи;

3) пов'язані з витребуванням доказів, проведенням огляду доказів за їхнім місцезнаходженням, забезпеченням доказів; 